\title{
Coexistence between the Formal and Informal Justice Systems in Ethiopia: Challenges and Prospects
}

\author{
Tsehai Wada Wourji* \\ Faculty of Law, Addis Ababa University, Addis Ababa, Ethiopia
}

\begin{abstract}
Though Ethiopia has never been colonized, the voluntary importation of European laws and the exercise in nation building has resulted in a situation whereby the formal and informal legal systems have to coexist in harmony or disharmony. Both systems are extant, though the future appears to be favourable for the prevalence of the formal system. This article argues that the informal system is showing signs of irrelevance and may be prevailed by the formal. It also counsels that the formal system should be helped to cleanse itself from the many shortcomings that are challenging its relevance and legitimacy.
\end{abstract}

\section{Keywords}

Ethiopia, legal pluralism, informal and formal justice systems, customary law and dispute settlement institutions

\section{Introduction}

As far as legal pluralism is concerned, the Ethiopian situation is not different from that of many African countries. The major difference is that Ethiopia imported foreign (European) laws voluntarily, while other states on the continent were coerced through colonization to adopt their colonizers' laws and legal systems.

A coerced transplantation of indigenous laws was practiced in Ethiopia, albeit with limited effects on the lives of the occupied people. Though the informal justice system used to exist de facto till the 1960s, it was expressly repealed as of this time and it is now given constitutional recognition as of $1995 .{ }^{1}$ The latter event appears to have given impetus to the resurgence of academic interest in the

\footnotetext{
*) E-mail: tsehaiwada@gmail.com. The author is an Associate Professor of Law at Addis Ababa University. This article is a result of a research grant given to me by The Danish Institute for Human Rights and done in Copenhagen, Denmark between August and December 2011. None of the statements, however, reflect the position of the institute and all shortcomings are mine.

1) For the purpose at hand, I have adopted Wajkowska's definition of formal and informal justice system. Accordingly, "[T]he formal justice system [...] involves civil and criminal justice and includes formal state-based justice institutions and procedures, such as police, prosecution, courts (religious) and custodial measures.
} 
area. The many theses produced and the few books published to date bear witness to this fact. ${ }^{2}$ These studies have attempted to canvass almost all major ethnic groups that are said to make use of the informal system than the formal. Nonetheless, none of them has attempted to assess the relevance or irrelevance of the formal system, the potency of the informal system in coping up with the burgeoning urban life style, the potential consequences of modern education, and resurgent religions, among others.

This article argues that the formal system is not as alien and irrelevant as argued by many researchers. In the same vein, it argues that evolving developments such as urbanization and more particularly rural - urban migration is seriously threatening the legitimacy and relevance of the informal system. The conclusion counsels that stakeholders should brace for the ultimate assimilation of the informal into the formal and this should be done through healthy dialogues than any coercive impositions.

The article has eight parts. The first part presents a brief political and legal history of Ethiopia followed by a second which offers a general theoretical framework within which the issues addressed can be discussed. The third part discusses the emergence and development of legal pluralism in the country as of the early 20th century. There then follows analysis of the current status of customary laws as reported by different local researchers who canvassed the customary justice systems of major ethnic groups in the country. The different challenges that pose threats to the informal system, as well as the challenges and opportunities of the formal system, are discussed in the two parts that follow subsequently. The conclusion attempts to chart the route towards a future harmonious coexistence between the two systems.

\section{A Brief Political and Legal History of Ethiopia}

Though Ethiopia has never been colonized, its history is, however, replete with civil and extra territorial wars. Besides those historical events that took place before the twentieth century, the conquest of the present day Eastern, Western and Southern Ethiopia, by Menelik II at the beginning of the 20th century has brought about profound consequences in terms of the current social harmony or

\footnotetext{
The term informal justice system[.... refer[s] to dispute resolution mechanisms falling outside the scope of the formal justice system." Ewa Wojkowska, Doing Justice: How informal justice systems can contribute (United Nations Development Programme, Oslo Governance Center, December 2006) 9.

2) A book written on the customary legal system of major ethnic groups, another on the Oromo legal system and the third that details the customary law of the Gurages, Gurage Peoples' Self- Help Development Organization, "Kitchal The Customary Law of Gurage" (September 2008), were published in 2008. See, infra notes 14 and 25 . Another book that has the same theme and scope as the first book mentioned above is published in 2011. See, infra note 25. Student theses are not published and not used in this work.
} 
disharmony. Given the fact that the conquest was achieved through bloody wars, the conquered people were forced to abandon their right to own land and exercise their right to self-determination, among others. Accordingly, they were forced to assimilate to the conquerors' religion, Coptic Christianity, and speak the conquerors' language, Amharic. ${ }^{3}$

Despite this fateful historical incidence, it is during this period that the genesis of a modern nation-state was laid down. The 'nation-building' project that was set in motion was carried over by the successors of King Menelik II, i.e., Haile Selassie I (1930-1974), the military government (1974-1991) and The Ethiopian Peoples' Revolutionary Democratic Front (EPRDF) (1991-to date).

Recorded history shows that Ethiopia had written laws as far back as the 14th century. One of these is the Feteha Negest (Justice of the Kings) that was availed by the monarchs between the sixteenth and twentieth centuries. This law was replaced by European laws imported as of the late 1950s. The first written constitution came into effect in 1931, together with the first formal Penal Code. Since then, three other constitutions and so many laws of foreign origin were enacted at different times. The process and the process continue today. Relevant parts of these laws, for the purpose of this article and their impact on the subject at hand, are discussed in subsequent sections below.

\section{A General Theoretical Framework}

It goes without saying that one of the challenges of legal pluralism is the competition - conflict or peaceful coexistence - between customary laws and dispute settlement institutions and the formal system. Any discussion pertaining to legal pluralism naturally raises many issues than meets the eyes, as a result of which, it will be unthinkable to cover them all in an article. For this reason alone, I will only briefly touch upon some of its salient features.

Customary law, which is one of the competitors of the formal law in a legally pluralist society, has the following salient features:

[It is] unwritten and [its] rules can be traced to the customs and practices of the people which have been handed down to succeeding generations. The law consists of different bodies of rules that may be invoked in different contexts. These rules are based on conceptions of morality and depend for their effectiveness on the approval and consent of the people. The law has evolved in response to the pressures put upon the people by their environment. It reflects their way of life and their adjustment

\footnotetext{
3) For details on the significance of this period, See, inter alias: J. Vanderlnden 'Civil Law and Common Law Influences on the Developing Law of Ethiopia' (1966-1967) 16 Buffalo Law Review 250-266; Norman J. Singer, A traditional legal institution in a modern legal setting: the Atbia Dagna of Ethiopia (1970-1971) 18 UCLA Law Review 308; Robert Allen Sedler, 'The Development of Legal Systems: The Ethiopian Experience' (1967-1968) 53 Iowa Law Review 562-635; and John W. Van Doren, 'Positivism and the Rule of Law, Formal Systems or Concealed Values: A Case Study of the Ethiopian Legal System' (Spring 1994) Journal of Transnational Law and Policy 165-204.
} 
to life in the particular society and environment. [...]. All unwritten customary laws, African or otherwise resemble each other more than any single customary system resembles any written system. ${ }^{4}$

In addition to the above, customary laws are said to be "suitable to people living in the same community who seek reconciliation based on restoration and who have to live and work together in the future"; "their norms and institutions [...] draw their moral authority from contemporary to traditional culture or customs, or religious beliefs, ideas and practices, rather than from the political authority of the state"; ${ }^{6}$ and "they tend to exist in small, generally rural communities dominated by $[\ldots]$ multiple relationships, that is, relationships which are based on past and future economic and social dependence which intersects ties of kinship."

An interesting feature of customary laws that sets them apart from the philosophy of conventional state/formal laws is that:

[L]egal rights and duties are primarily attached to a group rather than to individuals [...]. The individual plays a relatively subordinate role. Very often, the members of the group, as individuals, are only users of collective rights belonging to the family, lineage, clan, tribe or ethnic group as a whole. A law breaking individual thus transforms his group into a law breaking group, for in his dealings with others, he never stands alone. In the same vein, a disputing individual transforms his group into a disputing group and it follows that if he is wronged, he may depend upon his group for vengeance, for in some vicarious manner, they too have been wronged. ${ }^{8}$

Customary laws and legal systems were confronted by a powerful state law and legal system wherever and whenever the latter started to assert its authority over formal state functions i.e., law making, enforcement and adjudication. The emergence of the formal state thus created a situation wherein, customary laws and institutions have to compete against it. This new development in turn ushered in a state of plural legal orders wherein "a specific dispute or subject matter may be governed by multiple norms, laws or forums that co-exist within a particular jurisdiction or country [...] and diverse legal orders are superimposed, interpenetrated, and mixed". ${ }^{9}$ According to Tamanaha,

[W] herever there were movements of people, wherever there were empires, wherever religions spanned different language and cultural groups, wherever there was trade between different groups, or different groups lived side by side, it was inevitable that different bodies of law would operate or

\footnotetext{
4) A. Allot, Essays in African Law 3-10 (1960) in Sedler, supra note 3, p. 586.

5) Penal Law International, Access to Justice in Sub-Saharan Africa, The Role of Traditional and Informal Justice System (Astron Printers, London, 2000), p. 3.

6) International Council on Human Rights Policy, When Legal Worlds Overlap: Human Rights, State and Non-State Law (ICHRP, Versoix, 2009), p. 43.

7) Ibid., p. 22.

8) Ibid., p. 23. Note that these statements are made with regard to African societies, though they appear to be relevant to other societies as well.

9) International Council of Human Rights Policy, supra note 6, p. 6 and 7.
} 
overlap within the same social field. Since these were common conditions, the kinds of legal pluralism that existed in the medieval Europe no doubt existed elsewhere. ${ }^{10}$

Though formal state laws prevailed over customary laws in Europe, what came to pass in Africa and other countries after colonialism, could not allow the creation of such a state of affairs. Colonialism rather ushered in a new phase of legal pluralism wherein customary laws have to share their sphere with colonial laws that were superimposed on them. Accordingly, even after independence, former colonies could not easily abandon the colonial laws and legal systems, but rather retained them with differing positions on customary laws. Thus, customary laws were either given legal recognition or denied any space. The need to create nationstates and embrace modernity for which customary laws and legal system cannot offer solutions has compelled former colonies to retain the laws and legal systems of their former colonizers.

In those countries where customary laws are given legal recognition, their jurisdictions are by and large limited to personal, family and criminal matters - mostly over less serious crimes. Even within this limited jurisdiction, the norms and values enshrined in customary and religious laws are said to be inconsistent with constitutional and international human rights standards for which formal states have the duty to respect, promote and defend. Moreover, in those states wherein customary laws and their dispute settlement institutions are denied any recognition, they are extant and used by a majority of the populace. This reality has, therefore, forced many scholars and institutions to rethink their positions on legal pluralism as a result of which there is a nascent trend to study them in depth and chart the way forward.

The informal justice system may not necessarily be uniform in all places. Nonetheless, it appears that there are common features shared between them. These are presented below in light of their strengths and shortcomings.

Their dispute resolution institutions are, among other things, accessible; found within walking distance; employ local language; and typically, their procedures are simple and do not require the services of a lawyer. Their sanctions emphasize reconciliation, compensation, restoration and rehabilitation. They are participatory and give real voice to all - victims, offenders, and the society at large. Their processes help to prevent the escalation of conflicts that invite state intervention. Moreover, they are generally cost effective and speedy. These features make them preferable to the formal system, which is marred by delay, prison and court congestion, among others. ${ }^{11}$

\footnotetext{
10) Brian Z. Tamanaha, 'Understanding Legal Pluralism: Past to Present, Local to Global' (2008) 30 Sydney Law Review, 375-411.

11) For details, see Penal Law Reform International, supra note 5, p. 126 and 127; and Wojkowska, supra note 1 , p. 16-23.
} 
Despite these strengths, the system is discriminatory against women, children, and minorities, thus serving to reinforce existing hierarchies and social structures at the expense of these groups. Moreover, important constitutional rights such as the right to the presumption of innocence, freedom from degrading inhumane punishment, etc. are put in jeopardy, for factors such as past history of a suspect or relatives are taken into account to determine guilt and corporal punishments are resorted to in some cases. Though mediators are presumed to be neutral, they may, however, favour certain parties depending on their political allegiance, or power in terms of wealth, education or status, where not to do so might pose a threat to their authority. ${ }^{12}$

A comparative view of the two systems amply shows that one's strengths are the other's shortcomings. Accordingly, though the formal system is praised for its certainty, coercive sanctions, maintenance of human rights standards, etc., it is as well criticized for being remote to the ordinary user, costly, marred by delay, etc. In addition to the above, it suffices to note that the two systems differ in their approach to resolving a dispute. Thus, while the informal system attempts mainly to reconcile the disputing parties, the formal system takes this as an option but not an end in itself. The former relies on achieving a win-win end and the latter focuses on a zero sum game wherein the winner takes all. By way of conclusion for this section, it helps to note that though the above presentation has focused on major differences between the two systems, this should not be seen as suggesting that they are entirely dissimilar for they share many common features as well, as a result of which "the differences are a question of degree rather than substance." 13

\section{Legal Pluralism a la Ethiopia}

Ethiopia boasts a history of nationhood that is said to be over three thousand years old. Currently, it houses over eighty ethnic groups that profess different religions. This long history is replete with different wars fought between kings, religious and ethnic leaders, among others. The national boundaries have expanded or shrunk as a result of these wars.

Though each war had its own repercussions in terms of bringing together different peoples under one rule and redefining existing social relations, it appears that the current social relations owe their existence to the expansionist war waged at the beginning of the twentieth century. Menelik II's reign appears to have had more impact than the preceding kings. For it was at this time that the country's geographic size expanded and the genesis of a 'modern' state were established.

12) Penal Law Reform International, supra note 5, p. 127 and 128.
13) Ibid., p. 121. 
As far as legal history goes, the country's historical path can be divided into three distinct eras. Major developments that came to pass in each era as well as their impact on the issue under discussion are assessed below.

\subsection{Ethiopian Laws Up To the Early 1960s.}

Historians tell us that Ethiopia had written laws as far back as the 14th century. One of these laws, "the Feteha Negest" (Justice of the Kings) is said to have been imported from abroad, in the 16th century and had been used by different kings until the introduction of modern laws in the late 1950 s and early $1960 .{ }^{14}$ The Feteha Negest is an indigenized foreign law that aimed at governing the spiritual as well as secular lives of its subjects. The role of this law in introducing a new phase of legal pluralism is considered below.

It may be boldly asserted at the outset that this law had no strong influence in shaping the lives of the Ethiopian population till it was replaced by modern laws in the early twentieth century. Then and until the beginning of the 20th century, the different kingdoms that ruled the nation had limited power or the resource to penetrate into the hinterland, for they were limited mostly to the present day northern part of the country. Moreover, the Feteha Negest was intended to be applied on the Christian society, as a result of which, those living in the periphery as well as those which adhered to different religions could not be affected by it. This fact led some writers to opine that "the Feteha Negest was not widely applied among the highland Christians and it remained an esoteric document hardly known or used outside of the highest Imperial Courts" (the Emperors' Chilot)." 15 Another writer shared this view and had the following to say regarding the relevance of the law:

[The law] had far less importance and impact on everyday life than legal historians and scholars...generally attribute to it. [.... . [I] n a country where illiteracy is so high one can wonder about the exact influence of a text which only a small fringe of the population could read [...]. Most Ethiopians' legal life was governed by tribal customs and that it was only before church courts or before the highest among the lay courts (such as the Chilot) that [it] was invoked. ${ }^{16}$

It is noted above that the expansionist war waged in the late 19th century expanded the national frontier and brought different peoples under the fold of the central government. The national frontier that was drawn at this time is still intact, except for the secession of the former coastal province in 1991. Two important legislations were enacted when Haile Selassie I came to power in 1930 and these are: the

14) For more details, see Alula Pankhurst and Getachew Assefa (eds.) Grass-roots Justice in Ethiopia, The Contribution of Customary Dispute Resolution (French Center of Ethiopian Studies, Addis Ababa, 2008) p. 3 and the following (hereafter Pankhurst and Assefa, eds.).

15) Stanley Z. Fisher, 'Traditional Criminal Procedure in Ethiopia', (1971) 19 The American Journal of Comparative Law, 709-746, at p. 712.

16) J. Vanderlinden, supra note 3, p. 251. 
Constitution of 1930 and the Penal Code. The former confirms the consolidation of power by the Emperor and the latter covered criminal matters that were by then governed by the Feteha Negest.

\subsection{Ethiopian Laws Between the Mid-1950s and 1995}

As of 1955, Ethiopia started to enact modern laws aimed at propelling the nation into modernity. Accordingly, Haile Selassie's regime enacted a revised Constitution in 1955, a Penal Code in 1957, Civil, Commercial, Maritime codes in 1960 and procedure codes thereafter. All these laws were drafted by foreigners and had their origins in the respective laws of the countries of the drafters. The legal pluralism that was set in motion by the grand expansion, in which Northern values and religion were superimposed on the occupied peoples took another turn wherein European values were introduced through these major laws.

This particular period in time can be called "revolutionary" in terms of legal history, for at least two reasons. First, it introduced Western legal values in major areas of social activities that were unknown by the society and it changed the relationship between formal and customary laws in a very different manner than what used to be in the past. Thus a brief discussion about the role of customary and religious laws within the newly built edifice will be in order.

To begin with, it helps to note that as of this time, customary laws were denied any role in almost all spheres. Accordingly, the Civil Code repealed all customary laws. ${ }^{17}$ Despite this blanket repeal, some argue that "in certain cases customary law was incorporated into the codes either because it was considered sound and suitable or because it was too deeply rooted to be taken away". ${ }^{18}$ Accordingly, some provisions in the areas of family and succession, more particularly, the concept of illegitimacy in cases of succession, spousal succession, effects of divorce among others, are said to have been consistent with customary law.

Such statements cannot, however, oblige us to conclude that neither the drafters nor the law maker have attempted to incorporate all customary laws, for there was no single customary law that was practiced by a given majority of the population let alone the whole population. Thus, "the customary laws that are said to have been incorporated in the codes belong to the dominant Christian - Amhara, whose representatives also formed the Law Revision Committee and no one represented the values of the diverse minority groups, at the time". ${ }^{19}$ Moreover, "the codifiers apparently made no attempt to review existing written sources on customary legal systems in operation [...] much less to initiate or encourage system-

\footnotetext{
17) Article 3347 of the 1960 Civil Code reads as follows: "Unless otherwise expressly provided, all rules whether written or customary previously in force concerning matters provided for in this code shall be replaced by this code and are hereby repealed".

18) Robert Allen Sedler, supra note 3, p. 579-599.

19) Singer, supra note 3, p. 122.
} 
atic studies to supplement the scanty information available". ${ }^{20}$ "The Criminal Procedure Code does not specifically repeal customary practices neither does it commonly incorporate customary practices, either directly or by reference.... [It] is different from the existing traditional practices and draws heavily from the West" 21 and "the Penal Code makes no mention of customary law and was applied uniformly to all Ethiopians". ${ }^{22}$ These factors have then compelled one writer to opine that:

[T] hese laws have a predominantly Western flavour, and seem to bear little relation to the traditional patterns of life which still prevail in the Empire. [It is a] 'fantasy law', which may serve to put a modern 'face' on the country but, at least for some time to come, will not have any serious impact on the conduct of its affairs. ${ }^{23}$

The opinion of the latter writer appears to be closer to the truth, for the informal justice system is extant and used by a great majority of the public, even to date. On the other hand, the so called 'fantasy laws' are again in existence at least in the urban centers as well as in the rural parts where the formal justice system has penetrated. It should also be noted that these laws have served three political systems which adhere to completely different ideologies - Christian Monarchy, Marxist Military and ethnic federalism.

\subsection{Ethiopian Laws Between 1995 and the Present Day}

The precursor to the current state of affairs is the attempt to overhaul the whole legal system and revise important laws between 1974 and 1991, i.e., during the military regime. Though this regime enacted a revised constitution with Marxist flavours, its attempt to revise the other laws could not be realized, for it was initiated at the dying years of the regime. It appears that the relative peace gained after the fall of the military regime and the change in the international political order gave impetus to the adoption of a new constitution which is generous in terms of human rights. In the same vein, the 1995 Constitution drastically changed the relationship between the informal and formal justice systems. As of then, the informal justice system was accorded constitutional recognition. ${ }^{24}$

\footnotetext{
20) Fisher, supra note 15 , p. 711.

21) Ibid., p. 746.

22) Singer, supra note 3, p. 477.

23) Fisher, supra note 15 , p. 709-710.

24) The relevant articles read as follows:
}

Article 34 (5): This Constitution shall not preclude the adjudication of disputes relating to personal and family laws in accordance with religious or customary laws, with the consent of the parties to the dispute. Particulars shall be determined by law.

Article 78(5): Pursuant to Sub-Article 5 of Article 34 the House of Peoples' Representatives and State Councils can establish or give official recognition to religious and customary courts. Religious and customary courts that had state recognition and function prior to the adoption of the Constitution shall be organized on the basis of recognition accorded to them by this Constitution. 
A closer look at the relevant provisions of the constitution shows that further legislative acts are required to implement them. Nonetheless, the only piece of legislation enacted thereafter is Proclamation 188/1999 that has re-established the Sharia Courts. Thus, other laws and institutions are left to continue de-facto.

\section{The Current Status of the Informal Justice System}

Customary law in general or legal pluralism in particular was not a major area of academic interest for a long time. Though some publications have appeared at different times, it appears that the enactment of the Constitution and the political atmosphere created thereafter, have given impetus to the resurgence of discussions and debates on these subjects. Accordingly, in addition to many theses written by students, quite a few publications and a written customary law are published after 1995. Though some of these publications leave much to be desired, they throw some light on the status of customary laws and their dispute resolution institutions as practiced in the different parts of the country. Major features of the laws and institutions as reported in these publications are presented below. ${ }^{25}$

In almost all regions except for the Gurage, all customary laws are unwritten and pass from generation to generation orally. In almost all regions, elders figure in as the most ubiquitous form of dispute settlement mediums. In some others, clan, and religious leaders, as well as spirit mediums are presented as parallel institutions.

With regard to the types of disputes handled by these institutions, homicide is most common, followed by physical injury, insult, adultery, trespass, family matters, such as divorce, partition of property, succession, theft, and cattle raiding. Inter and intra ethnic clashes and settlements are also ubiquitous.

The most common type of sanction imposed by the institutions include: reparation of damage through compensation, reconciliation between the disputing parties and their families or clans, curse, banishment, and occasionally, corporal and even capital punishment. Since none of the societies studied have prisons to keep their criminals, they resort to banishment of the individuals from the community till the desire to avenge cools down, or sheltering an accused in the houses of elders or churches. Their decisions are executed voluntarily and failure to heed this may result in ostracism and curse.

\footnotetext{
Per Article 55(5), the federal legislature has the sole authority to enact penal code, while regions are given the authority to legislate criminal matters not covered by the former.

25) The following findings are drawn from the following publications: Pankhurst and Assefa, supra note 14, Gebre Yntiso, Fekade Azeze and Assefa Fiseha (eds.) (hereafter Yntiso et al., eds.), Customary Dispute Resolution Mechanisms in Ethiopia (The Ethiopian Arbitration and Conciliation Center, Addis Ababa, 2011); and Tsegaye Regassa, Urgessa Genemo and Tena Yigezu (hereafter Regassa et al.), Restorative Justice in Oromia: Baseline Study (Justice for All and Prison Fellowship Ethiopia, Addis Ababa, 2008) passim.
} 
It appears that 'oath' has a decisive role in determining the outcome of a case. Accordingly, in most cases where a suspect/an accused denies an allegation made against him/her, the plaintiff/accuser will be required to call witnesses - who are also required to take oath - and if still a case against the accused is not made, then s/he will be relieved of any liability. In some cases, not only an accused, but also all his close relatives will be required to take oath. In almost all cultures studied, it appears that there is a strong reliance on oath as well as a presumption that no one will lie while under oath for such behaviour will be a harbinger of future disasters upon oneself or close relatives.

Whether or not children are better or less protected under the customary law and institutions is not clearly shown in the literature. Despite this, in so many places, women are denied the right to participate in dispute settlement institutions, or even present their own cases, without representation. Moreover, in some places like in Gurage, the informal system allows a husband to practice polygamy, and the wife he divorced cannot marry another without his consent. ${ }^{26}$ Minorities are said to have been marginalized in some places. ${ }^{27}$

It has been reported that the customary and formal institutions are cooperating with each other in quite a few places while in so many others they exist in separation without acknowledging each other's existence.

\section{A Critical Evaluation of the Ethiopian Informal Justice System}

Though local literature have contributed a lot to knowledge in this specific area and this is commendable, as noted at the introductory part and the following paragraph, they are less critical. Noting their contribution, it should not be assumed that fault finding is the major thrust of this article. Nonetheless, the fact that the informal justice system is under threat emanating from the formal system as well as religions, and urbanization, among others, is an important issue to be reckoned with. In the same vein, it will be shown below that the informal system has major shortcomings that may threaten its very existence and there are facts on the ground that show that the formal system is gaining strength at the cost of the former.

Almost all literature generated in Ethiopia are written in a narrative form wherein researchers have limited their scope to presenting facts as they are without much focus on important issues such as, the potency of the formal state law and its institutions, the role of customary laws and institutions in reducing recidivism or even crime prevention, and their shortcomings. Shortcomings in

\footnotetext{
26) Yewndwessen Awlachew, 'Yeajoka Kicha - The System of Dispute Resolution in Sebat Bet Gurage', inYintiso et al. (eds.), supra note 25, p. 60.

27) See Section 7.1, paragraph 3 below.
} 
particular are presented as incidental issues in many of the publications and this is a rare incident. ${ }^{28}$

\subsection{Accessibility and Relevance}

There is no gainsaying the fact that much of the Ethiopian population relies on the informal justice system. ${ }^{29}$ Despite this, it appears that urbanization in general and rural-urban migration in particular is increasing over time. This trend will bring the formal system closer to the public and threaten the relevance of the informal system for the former is more relevant in city centers than the latter.

\subsubsection{Effects of Urbanization}

Though an official statistical data put the rate of at a much lower percentage (2\%) between 1984 and $2007,{ }^{30}$ more focussed research shows that the percentage is much higher than this. A major study reached the following conclusions, which are worth reproducing in full:

[T] he level of urbanization has been very low, which only got momentum during the post WWII period associated with the introduction and consolidation of modern government bureaucracy, transport systems, public services, etc. The level of urbanization was only 3 percent at the end of WWII, which increased to 6 percent in 1960, 11 percent in 1994 [probably 1984?] and 14\% in 1994 , which is estimated to have already reached 16 percent in 2003 and projected to account for $20 \%$ of the total population in the year 2020. ${ }^{31}$ Evaluating Ethiopia's urban growth using the agglomeration index methodology shows that urbanization growth rates are much higher (between 8 and 9 per cent) than previously calculated by the CSA. Whereas, CSA estimated 1984 urbaniza-

\footnotetext{
28) The only exception is the book edited by Yntiso et al., supra note 25 , for each study contains a section that deals with the interface between the formal and informal systems.

29) Note: The only instance wherein the percentage of users is reported is the case of "Afar and Somali", where "over 90\% of the population still avails customary laws", Getachew Talachew and Shimelis Habteweld, 'Customary Dispute Resolution in Afar Society'; and Mohammed Mealin Seid and Zewdie Jotte, 'Customary Dispute Resolution in the Somali Region on Ethiopia: An Overview', in Pankhurst and Assefa (eds.), supra note 14, p. 96 and 186, respectively. A great majority of the population is by and large nomadic and the regions are volatile in terms of security. Thus, the percentage does not show a mainstream trend, but an exceptional phenomenon. Moreover, official data show that the number of cases submitted to formal courts is increasing through time. Accordingly, 3944 civil and 8,781 criminal cases and 4391 civil and 5814 criminal cases were submitted to courts in 2008/2009 and 2009/2010 in Afar Region, respectively. In the Somali Region, 193 civil, 315 criminal, 3165 civil, 1324 criminal, 7762 civil, 3915 criminal cases were submitted to courts in 2009/9, 2009/10 and 2010/11, respectively. See Central Statistics Agency (hereafter CSA) Statistical Abstract (2011). These figures may contradict and belie the above assertion or at least show that the relevance of the formal system is increasing through time.

30) "[T]he urban population has increased by $2 \%$ while the rural population has decreased by $2 \%$. The percentage of the rural population was 86\% in 1986 and 84\% in 2007", FDRE Population and Census Commission, Summary and Statistical Report of the 2007 Population and Housing Census (Addis Ababa, 2007) p. 19.

31) Ministry of Federal Affairs, National Urban Planning Institute, Urban Development Policy Design Project Office, Urban Development Policy Inception Report (Addis Ababa, 2003), Section 1.3.
} 
tion at 11.4 per cent, the agglomeration index calculated urbanization at 3.7\%. Between 1984 and 1994 and between 2007, the percent urban doubled according to the agglomeration index. ${ }^{32}$

$[\mathrm{U}]$ rban growth has grown rapidly over the last 3 decades. Since the previous census in 1994, new cities were created, and economically viable cities have experienced large growth in population count and density. ${ }^{33}$

Indeed, unless policies actively impede urbanization, Ethiopia will most likely have urbanization rates of 30 percent or more within the next two decade. ${ }^{34}$ Despite [Ethiopia's] low level of urbanization, however, the country has one the highest rates of urbanization, even by the standards of developing countries, which is estimated at 5.4 percent during the inter census period (1984-1994). This is also much higher than the average growth rate of the total national population, which is estimated at 3.4 percent. $^{35}$

The formal laws and institutions are more relevant than the customary ones in urban centers so much so that it is unthinkable to settle serious cases more particularly, criminal matters, through customary laws and institutions in the these larger centers. Accordingly, the above figures are beacons to the gradual decrease in potency and relevance of the informal system as well as the gradual increase in accessibility of the formal courts. Moreover, research findings clearly show that the establishment of formal courts have almost displaced informal courts in some places like: Neurland in Gambella, ${ }^{36}$ Sidama, ${ }^{37}$ and Arsi, in Oromia, ${ }^{38}$ among others.

\subsubsection{Loss and Transformation of Major Features}

Whether as a result of the above phenomenon or other factors, the informal system has indeed lost significance in some places. The following facts, though often presented as incidental information in the respective researches, buttress this assertion.

\footnotetext{
32) International Food Policy Research Institute - Ethiopia Strategy Support Program 2, Ethiopia, The Rural-Urban Transformation in Ethiopia (Addis Ababa, June 2010) p. 16 and 17. Note that the major difference between the two estimates lies in the definition of an urban center. CSA defines an urban center as a place that is officially designated as such and that has a population of 1000 people who are primarily engaged in non-agricultural activities. The latter estimate defines an urban center as a locality that has a population density greater than 150 people per square $\mathrm{km}$ and located within one hour travel time from a city of at least 50000 people.

33) Ibid., p. 20.

34) Ibid., p. 42. For further details, see, Ethiopia Strategy Support Program II (ESSP II) and International Food Policy Research Institute (July 2011), The Rural-Urban Transformation in Ethiopia (Addis Ababa, July 2011).

35) National Urban Planning Institute, 2003, supra note 31, Section 1.3. According to this study, the major factors for this high rate of rural-urban migration are among others: push factors such as deterioration of resource balances, and pull factors such as the fact that urban areas are relatively better off than the rural population in terms of availability of job opportunities and social services.

36) Pankhurst and Assefa, eds., supra note 14, p. 26.

37) Ayke Asfaw and Mekonnen Feleke, 'Customary Dispute Resolution in the SNNPRS: The Case of Sidama', in Ibid., p. 213.

38) Tolosa Manuye, 'The Sinquee - Women's Institution for Conflict Resolution in Arsi', in Yitniso et al. (eds.), supra note 25 , p. 294.
} 
As recently as the 1950s and 1960s, local customary criminal justice systems used to employ different mechanisms to identify suspects. Nonetheless, none of the recent research mention their existence. Accordingly, 'Afersata' which used to be employed to screen potential wrong doers in a public gathering are no more extant; the so called 'Leba Shai' system, in which a very young person used to be drugged and dragged in a given locality to seek a wrong doer, has also vanished; 'Kuragna' wherein a suspect used to be tied with an accuser till brought to the nearest judge is no more operative. ${ }^{39}$

In the Amhara Region, a criminal used to run to a nearby church and ring a bell, after which act no one would have dared touch him till the case is settled through the customary means. But, researchers have recently found out that "this form of symbolic apology was commonly used in the past.... [though]it is [only] occasionally used in the countryside [at present]..$^{40}$

It may be argued that in the above cases, people are no more 'innocent enough' to accept guilt or be brought to justice through such out-dated mechanisms. The total absence of these mechanisms has forced the informal system to rely on oath as the only means of screening suspects.

\subsubsection{The Contributions of Religions, Education and Secularity to the Irrelevance of the Informal System}

Evangelization and conversion to Coptic Christianity among others have negatively impacted customary laws in Gambella and Sidama among others. ${ }^{41}$ In Arsi Zone, Oromia, where 'Sinquee' (a women's dispute settlement institution) has been practiced for centuries, Protestantism and Wahhabism among others have almost displaced the institution so much so that its very existence is put into question. ${ }^{42}$ The same trend is noted to have challenged the Gada system in Borena and Guji, in Oromia. ${ }^{43}$

Modern education and secularity have also contributed to the increasing irrelevance of the informal system as noted in Shekacho, Arsi, Borena and Guji in Oromia, among others. ${ }^{44}$ The generation gap has also threatened the futurity of the informal system as witnessed in some places in Oromia. Accordingly,

[I]n recent years [the popular legitimacy of the informal system] is diminishing, especially as the younger generation considers the elders as relics of the past that is irrelevant. The richer the youth,

\footnotetext{
39) For more details on these practices, see Stanley Z. Fisher, supra note 15.

40) Melaku Abate and Wubshet Shiferaw, 'Customary Dispute Resolution in Amhara Region: The case of Wofa Legesse', in Pankurst and Assefa (eds.), supra note 14, p. 108.

41) Pankhurst and Assefa eds, p. 14; and Ayke Asfaw and Mekonnen Feleke, supra note 37 p. 203.

42) Tolosa Manuye, supra note 38, p. 294 and 295.

43) Israel Itansa, 'The Quest for the Survival of the Gada System's Role in Conflict Resolution', in Yintiso et al. (eds.), supra note 25 , p. 318.

44) Sileshi Abate, 'The System of Dispute Resolution in the Shekacho Society', Tolosa Munye, supra note 38 and Israel Itansa, Ibid., in Yintiso et al. (eds.), supra note 25, p. 78, 294 and 319, respectively.
} 
the less it respects the authority of the elders. They think they can kill anyone for they can pay the blood money, and get away with it. Sometimes, the elders said, [they] are afraid of the youth for their lives, especially if there is a case they have at stake in, and in which they suspect the elders are going to decide against them. ${ }^{45}$

\section{Questioning the Stereotypical Assumption that Customary Polities are Pure in the True Sense}

\subsection{The Sustainability of Pure Societies}

It has been noted above that customary laws suit rural and small communities that share similar values, their members know each other and their settlement of disputes before they degenerate into further violence is a necessity borne out of common life. Such a society/community may be called as a 'pure society' for the purpose at hand. Sanctions such as reconciliation and compensation aim at averting further conflict between members of clan/ethnic members of the wrong doer and the wronged. Nonetheless, customary laws do not have a mechanism whereby a non-member is either a victim or wrong doer, for in such cases there will not be anyone to seek compensation or to be reconciled with or threatens to avenge the wrong done. At least one report from the Afar Region shows that such cases are dealt by the formal system. ${ }^{46}$

It goes without saying that almost all cultural polities are affected by the cultures of others living with them such as migrants, urban life styles, or even foreign norms and values disseminated through the media, among others. Thus, there is an apparent tendency that shows that cultural polities will through time change to a cosmopolitan one wherein customary laws will have less significance. The fact that it is almost unthinkable among urban dwellers in so many parts of the country to settle criminal matters, especially serious crimes such as murder, through the informal system appears to bear witness to this trend.

The transformation of cultural societies may also put into question the two most prominent pillars of the informal justice system, i.e., innocence of oath takers and the incorruptibility of mediators. It is pointed out above that in the absence of out-dated screening mechanisms the informal justice system is left with oath as the only means of identifying suspects. Though the formal system also employs this as one of its mechanisms, it also employs other mechanisms, such as forensic examination which is not available to the informal system. The underlying assumption in the informal system is that 'nobody will tell lie/perjure while under oath', for all members are innocent. Nonetheless, education, secularity and urban life styles, among others, contribute to the increase in the number of peoples that do not take the consequences of perjury seriously. Researchers

\footnotetext{
45) Regassa et al., supra note 25, p. 139.

46) Pankhurst and Assefa (eds.), supra note 14 p. 10.
} 
have shown that "the major problem faced nowadays is the problem of false testimony, especially in cases pending in courts. People tend to take advantage of the presumption of innocence..." 47

Mediators, whether they are elders, religious leaders or spirit mediums are presumed to stand above corruption in almost all customary societies. Moreover, though in principle they offer their services free of any charge, disputants, more particularly those who lost their cases or adjudged liable for a given damage are required to cover the expenses of feasts. Mediators are also praised for their celerity in the disposition of cases. Notwithstanding these virtues, there are reported instances which indicate that these virtues may be lost in the future. The following quotes illustrate this assertion:

[In the Amhara Region] with regard to disputes between husbands and wives, the male decision makers tend to side with the men against women. [...]. The position of the wife is undermined during the investigation of divorce cases. Divorce cases do not get immediate attention since traditional/cultural decision makers are very reluctant to admit women's equality with men. ${ }^{48}$

Gada is an ancient administrative, legislative and judicial institution with which all Oromos - the majority ethnic group in the country - are proud of. Its meetings are held periodically and in a democratic manner. Nonetheless, recent research demonstrate among others that: the heads of the institution - the Aba Gadas - have failed to attend the meetings, for they are busy attending workshops organized by the government; they are highly politically involved or put differently, coopted by the latter; their elections are manipulated and they often abuse their power and misbehave in public places. The legitimacy of the institution is, therefore, put into question. ${ }^{49}$

Celerity in the informal system is borne out of the small number of cases submitted to the customary fora. Nonetheless, given the inevitable increase in population size, cases will increase in a proportionate manner and there may come a time when 'delay' that characterizes the formal system will also be a feature of the customary system. It may be argued that it is this small volume of cases that encourages mediators to sacrifice their free time without charging any fee. As confirmed by at least one report, increase in the volume of cases will nonetheless compel them either to refuse their services or to charge disputants:

\footnotetext{
47) Regassa et al., supra note 25 , p. 135 . Note: The statement is meant to show that people may not perjure in informal courts. Nonetheless, such individuals care less to perjure in formal courts, provided that the prosecution cannot submit reliable evidence against them. Such individuals are so smart and calculative and one wonders whether they can be trusted at informal courts.

48) Melaku Abate and Wubshet Shiferaw, supra note 40, p. 111.

49) Israel Itansa, supra note 43, p. 299-320. Note: Co-optation by the government is also practiced in other places, such as in Shinasha, in Beni Shangul and Semen Shoa, See Yintiso et al. (eds.), supra note 25 , p. 455 and $174-180$, respectively.
} 
[in Tigray Region, Irob Wereda], elders complain shortage of time to work on their farms and private matters $[. .$.$] as well as lack of a mechanism which allows them seek compensation for the time$ spent in dispute resolution, [as a result of which], they are unwilling to take part when the litigants cannot afford to give services (such as feasts, transportation allowance, etc.) and that their number is decreasing through time..$^{50}$

Thus, in the absence of any mechanism that allows for the remuneration of mediators either by the state or disputants, which may also impinge on their legitimacy, this virtue of the customary system may be lost through time.

\subsection{The Protection of Human Rights}

It should be noted from the outset that Ethiopia is a party to most of the international human rights conventions and the African Charter on Human and Peoples' Rights. ${ }^{51}$ Moreover, the human rights provisions of the country's Constitution heavily draw from these conventions so much so that some of its provisions are verbatim copies of the latter. International conventions ratified by the country are also given equal status with formal laws of the land, but do not prevail over the Constitution. ${ }^{52}$

50) Shimelis Gizaw and Tadesse Gessese, 'Customary Dispute Resolution in Tigray Region: Case Studies from Three Districts', in Pankhurst and Assefa (eds.), supra note 14, p. 232.

51) Ethiopia has ratified the following conventions on the dates indicated at the end:

ICERD (International Convention on the Elimination of All Forms of Discrimination) 1965 - Date of ratification 23 June 1976 - No reservation

ICESCR (International Convention on Economic, Social and Cultural Rights) 1966 - 11 June 1993 - No reservation

ICCPR (International covenant on Civil and Political Rights) 1966 - 11 June 1993 - No reservation CEDAW (Convention on the Elimination of All forms of Discrimination against Women) 1979 10 September 1981 (8 July 1980 - Eth doc.) - Reservation to Article 29(1)

CAT (Convention against Torture and Other Cruel or Degrading Treatment or Punishment) 1984 14 March 1994 - No reservation

CRC (Convention on the Rights of the Child) 1989 - 14 May 1994 - No reservation

The African Charter on Human and Peoples' Rights (the African Charter) on 15th November 1998.

See UN GA, Human Rights Council, Working Group on the Universal Periodic Review, Sixth Session, Geneva, 39 November-11 December 2009, A/HRC/ WG.6/6/ETH/2, available online at http://www2 .ohchr.org/english/bodies/hrc/sessions.htm (accessed on 4 September 2012); and African Commission on Human and Peoples' Rights, Forty-Seventh Ordinary Session, 12-26 May 2010, Banjul, The Gambia, Consideration of reports...concluding observations and recommendations...Periodic report of the FDRE, available online at http://www.achpr.org/states/reports-and-concluding-observations/ (accessed on 4 September 2012).

52) Relevant parts of the Constitutions read as follows:

Article 9(1): The Constitution is the supreme law of the land. Any law, customary practice or a decision of an organ of the state or a public official that contravenes this Constitution shall be of no effect.

Article 9(4): All international agreements ratified by Ethiopia are an integral part of the law of the land.

Article 13(2): The fundamental rights and freedoms specified in this Chapter [Chapter Three, Fundamental Rights and Freedoms] shall be interpreted in a manner conforming to the principles of the Universal Declaration of Human Rights, International Covenants on Human Rights and international instruments adopted by Ethiopia. 
Research done in different parts of the country amply prove that major rights that are given due recognition under the Constitution as well as those international human rights instruments that are ratified by the state are put in jeopardy in the informal system. The equality of genders, the right to the presumption of innocence, freedom from inhumane and degrading punishments, and the rights of children and minorities, among others, are widely violated..$^{53}$ Noting that the government has the duty to promote and protect all these rights and it is doing this under the watchful eyes of human rights watch dogs, ${ }^{54}$ it will be axiomatic that its institutions are implementing them in a better manner than the informal ones. Accordingly, those whose rights are violated - more particularly the marginalized ones - will naturally tend to resort to the formal system, as shown in the case of the Gurages whose women are witnessed to have successfully overturned

53) All these rights and freedoms are given constitutional recognition. The relevant provisions of the Constitution read as follows:

Article 18: Prohibition against Inhuman Treatment - (1) - Everyone has the right to protection against cruel, inhuman or degrading treatment or punishment.

Article 20: Rights of Persons Accused - (3) - During proceedings accused persons have the right to be presumed innocent until proved guilty according to law and not to be compelled to testify against themselves.

Article 25: Right to Equality. - All persons are equal before the law and are entitled without any discrimination to the equal protection of the law. In this respect, the law shall guarantee to all persons equal and effective protection without discrimination on grounds of race, nation, nationality, or other social origin, colour, sex, language, religion, political or other opinion, property, birth or other status.

Article 35: Rights of Women. (1) Women shall, in the enjoyment of rights and protections provided for by this Constitution, have equal rights with men. (2) Women have equal rights with men in marriage as prescribed by this Constitution. [sub- arts.3-9 are omitted].

Article 36: Rights of Children - Every child has the right, to inter alia: life, name, nationality be free from corporal punishment or cruel and inhumane treatment in schools and other institutions responsible for the care of children.

54) Though the country has been heavily criticized for the violation of rights - mainly civil and political rights - by international and local human rights watchdogs, it has not benefited from the recommendations of the UN Human Rights Committee and the African Charter Periodic Review. This is so because the country submitted its first periodic reports ten years after the entry into force of the African Charter on Human and Peoples' Rights and seventeen years after the entry into force of the International Convenant on Civil and Political Rights. See, supra note 51, Federal Democratic Republic of Ethiopia, Combined Report (Initial and Four Periodic Reports) to The African Commission on Human and Peoples' Rights, Implementation of the African Charter on Human and Peoples' Rights, supra note 51, para. 3, p. 7 and Human Rights Committee, and supra note 51, 102nd Session, Geneva, 11-29 July 2011, Consideration of reports submitted by state parties under article 40 of the covenant, Concluding observations of the Human Rights Committee, Ethiopia CCPR/C/ETH/CO/1, para. 2, respectively.

Probably the only time when the Human Rights Committee raised the issue of 'traditional justice and customary courts' is when it considered the Country's report in July 2011. Accordingly, it asked, "In terms of traditional justice and customary courts, what happened when their positions ran counter to the provision of the Covenant?" Very unfortunately, the Ethiopian delegation did not respond to the question and the Committee did not raise the issue again. See United Nations Human Rights Committee, News \& Media, Human Rights Committee Considers Report of Ethiopia, 12 July 2011.

The issue of the discrimination of women, children and minorities has been raised as a cause of concern by both bodies and the response of the delegation is that, it is doing its best to ameliorate the situation. 
judgments given by the informal courts regarding their right to inheritance of properties from their parents which they are denied in the informal system. ${ }^{55}$ Thus, unless the informal system can align its human rights standards with the formal system, it may lose its legitimacy and fall into disuse. The caveat is that this may not be realized in the immediate future as such fundamental changes to any legal system of law will probably take time.

The informal system has many other features that may threaten its previous influence. This does not mean that the formal system is perfect, but far from this. Nonetheless, the different developments noted above, such as urbanization, secularity, and education among others, suggests that it will be the major justice provider in the future. With this assumption, the challenges it is faced with and the opportunities it offers are discussed below.

\section{Challenges and Opportunities}

\subsection{Enactment of Enabling Legislations}

In contrast with the former legal position that expressly repealed customary and religious laws and their dispute settlement institutions, the constitutional recognition given to them in the 1995 constitution is indeed a plus for legal pluralism. A closer look at the relevant constitutional provisions, i.e., Articles 34(5) and 78(5), however, indicates that further legislative acts are required to implement this right. Nonetheless, the only piece of legislation enacted to this effect - at the federal level is Proclamation No. 188/1999 that [re] established the Sharia Courts. ${ }^{56}$ Though customary and religious laws are not necessarily required to be enacted by anyone of the legislatures, their courts cannot, however, function without legal recognition. In the same vein, the formal courts can neither hear appeals from their decisions nor enforce them. Thus, as things stand at present, the situation is back to square one and the two systems coexist through 'reciprocal ignorance'. Given the multifarious claims made by different ethnic groups, which includes secession, the fact that nothing is done in this regard for the past two decades is at best confounding.

As the following quote amply shows, it appears that charting the future through legislative acts has reached a dead end:

According to most officials, the current system, whereby federal law is not forcefully implemented against customary and religious law, is working well. People at the grass root level are said to be satisfied with it, and not to require any changes. Officials and former judges [...] all express the strong view that nothing should be attempted against religious or customary law at this stage. This would most probably be extremely counterproductive and fire back on the government. Customary

\footnotetext{
55) Yewndwessen Awlachew, supra note 26, p. 59.

56) Some regional legislatures have also enacted similar legislation.
} 


\begin{abstract}
law is indeed deeply entrenched in peoples' minds, and has been enforced for centuries. The central powers in the past never attempted to force and implement effectively central government laws on people abiding by customary law [...]. This system of religious, customary and social courts will remain the only effective tool for such justice in the country for as long as the Federal Court system remains in such dire straits and disarray. Under such conditions in the "regular" federal court system, it is neither reasonable, nor justified, to seek a rapid submission of religious and customary law to he federal system of courts. This could only but fail..$^{57}$
\end{abstract}

Noting that criminal matters are beyond the jurisdiction of the customary or religious courts, there are some reports that show that they do indeed handle such cases with the cooperation/tacit approval of the officials of the formal system. Accordingly, in the Afar Region, two homicide cases in which a murderer had admitted guilt and another found guilty on appeal were processed under the customary system upon the request of elders who petitioned the State Council to transfer the cases to their customary courts. The Council instructed the Regional Justice Bureau - Prosecution Office - to drop the charges and the latter conceded by citing Article 42(1) of the Criminal Procedure Code. ${ }^{58}$ Yet in another region Somali, "the government army may be incapable of ensuring peace and order [....]. [As a result of which], government officials unconditionally enforce decisions of the elders, even when the latter contradict the law." 59

The two regions are inhabited by pastoralists and volatile in terms of security. Thus, such 'cooperation' can be taken as an aberration than a mainstream practice. Despite this, there are many instances wherein the two systems are cooperating either through tacit agreements that at least criminal cases should be entertained in the formal courts alone and officials of the informal system are invited to settle disputes - most likely civil cases - through their own institutions. ${ }^{60}$ The de facto existence of the informal system is seen to have created uneasiness in so many places wherein the officials of the formal system snatch criminals who have exhausted their trial at the informal system. This typically creates much resentment in the latter. ${ }^{61}$ This is therefore a major shortcoming of the formal system that needs to be addressed as soon as possible.

\footnotetext{
57) Center for International Legal Cooperation (Consultant), FDRE, Comprehensive Justice System Reform Program Baseline Study Report, Ministry of Capacity Building (Leiden, February 2005) p. 157 and 158.

58) Getachew Talachew and Shimelis Habteweld, supra note 29 p. 103-105. Note that the article cited does not allow for disposition of cases in such a manner.

59) Mohammed Mealin Seid and Zewdie Jotte, supra note 29, p. 194.

60) See inter alias: Sileshi Abate, supra note 44, Yilma Teferri, 'The System of Arbitration by elders and conciliation in Wolaita Society', Abraham Tadesse, 'Customary Dispute Resolution in Sidama Society'; and Berhan Assefa, 'The Judgment of Amare in Borena Weredas, South Wello', all in Yintiso et al. (eds.), supra note 25 , p. $78-80,116,131$ and 153 , respectively.

61) Sileshi Abate, supra note 44 and Israel Itensa, supra note 43, p. 80 and 318, respectively.
} 


\subsection{The Status of Ethiopian Courts}

\subsubsection{Judicial Independence}

The right to forum shopping can be meaningfully exercised where both systems offer their institutions for use. It may be argued that this is an impotent right at present for much of the Ethiopian public cannot access formal courts. Nonetheless, it is shown above that the problem of inaccessibility will fade away through time primarily because of urbanization. In the same vein, formal courts will need to prove that they can offer better services than the informal ones. In order to do this, they need to be independent; and this is their Achilles heel, as proved by many researchers. Different authors posit among other things that:

[T] he judicial system is afflicted with, inter alias: corruption, abuse of power and political interference within the administration of justice, [...] limited independence of judges, lack of systems for holding judges accountable for misconduct, very limited confidence of the general public in courts and other institutions of the administration of justice. ${ }^{62}$

Moreover, the system is said to be "generally characterized by delays in the dispensation of justice, lack of institutional capacity in law enforcement, [...] court congestion [and that] programs designed to bring about a fair and efficient system of justice in the interest of the people have not yet fully lived up to expectations". ${ }^{63}$

According to an assessment report of the World Bank,

[A] long history of centralized governmental authority and a judiciary subjugated to the executive branch has fostered a weak judicial branch with reduced capacity to exercise a genuine independence, as well as a reticence of other branches to treat the judiciary as either truly independent or co-equal. ${ }^{64}$

All these are indeed major threats that confront the formal system. Despite these shortcomings, however, it helps to note that many regions are making use of their own languages for court and other official businesses. This has ushered in a new era of autonomy wherein people are no longer forced to use one official language only. This indeed is a plus for the formal system.

\subsubsection{Cost and Delay}

The stereotypical assumptions relative to cost and delay imply that these are the strengths of the informal system and shortcomings of the formal. Nonetheless, these assumptions are only partly true in the Ethiopian case. With regard to cost, criminal cases are processed at state expense and civil cases can be processed freely,

\footnotetext{
62) Center for International Legal Cooperation, supra note 57, p. 159-179.

63) Commission on Legal Empowerment of the Poor (CLEP), Background issue paper on Legal Empowerment of the Poor: Access to Justice (Addis Ababa, 12 November 2006), p. 1.

64) Legal Vice Presidency, The World Bank, Ethiopia Legal and Judicial Sector Assessment (Washington, DC, 2004), p. 19
} 
if the plaintiff is an indigent. ${ }^{65}$ Noting that litigants in the informal system have the duty to cover costs of feasts after conciliation and that many indigent litigants in city centers are seen making use of their right to institute civil claims freely 'forma puperis' - criticisms levelled at the formal system in this regard do not hold water.

Delayed justice is undoubtedly one of the burning issues in Ethiopia. ${ }^{66}$ Accordingly, though there are many attempts to alleviate this problem such as the introduction of a modern case management system, online access to information, video conferencing, etc., the right to the attainment of a standard timely justice is not yet realized. The informal system excels the formal in this regard and this is engendered by the volume of cases, which is naturally very small compared to the formal one. The latter is on the hand burdened by the volume of cases mostly due to a mismatch between the number of cases and personnel handling the cases. The formal system has recently recorded notable achievements in this regard, though resource limitation has not enabled it to cope up with the ever increasing volume of cases. ${ }^{67}$

\subsection{The Status of Advocacy Civil Societies}

Ethiopian civil society organizations came out of years of slumber and recorded colourful achievements in a short span. Accordingly, they were instrumental in the dissemination of human rights as well as lobbying for the enactment of rights friendly laws. Nonetheless, Proclamation No. 621/2009, that was expected to bless them with strong legal guarantees, ended up being a brush to wipe them out of existence. The requirement that advocacy groups need to raise $90 \%$ of their income locally, among others, has led to their failure to reregister and thus the extinction of many. ${ }^{68}$ This indeed is a major threat to the formal system that needs a sensitized public that prefers its use over the informal one.

\section{Charting the Route towards a Future Harmonious Coexistence}

As things stand at present, both systems function within their respective geographical spheres. Such coexistence appears to be 'peaceful' so far, for no major

\footnotetext{
65) Civil Procedure Code of the Empire of Ethiopia, Extraordinary Issue No. 3 of Arts (1965) 467-479.

66) For further details, see Tsehai Wada, 'Timely disposition of Criminal Cases in Ethiopia' (2010) XII Journal of Ethiopian Law.

67) Although some of the studies quoted in this article are written by lawyers, none of them mentions the legal framework that governs compensation in tort under the Civil Code, and it appears that the silence tantamount to a suggestion that compensation is a unique feature of the informal system alone but this is not so.

68) For more details, see Task Force on Enabling Environment for Civil Societies in Ethiopia, Kumlachew Dagne and Debe Hailegebries, 'Assessment of the Impact of the Charities and Societies Regulatory Framework on Civil Society Organizations in Ethiopia' (June 2012).
} 
conflict is recorded. It is shown above that the informal system is given the remit to entertain civil cases that may fall within personal and family category, but not criminal matters. Nonetheless, its importance as a restorer of disturbed social relations looms large in the latter types of cases and it is doing this without any legal recognition. The absence of enabling legislations has led to a situation wherein all cases, whether civil or criminal, are being entertained de novo at both forums thus leading to opportunistic forum shopping. This status should not be allowed to continue ad infinitum, for nothing will be gained from it. Hoping that the time to enact enabling legislations will come sooner or later, this section will attempt to forward pre-emptive solutions to a future harmonious coexistence.

\subsection{Jurisdiction}

The only conflict between the two systems relates to non-personal and family civil matters and criminal cases. With regard to civil cases, parties are in principle at liberty to forgo their right to lodge claims or even withdraw them while still under formal litigation. Thus, in the absence of a compulsory jurisdiction, a situation that can pit the systems against each other should not normally arise. In criminal matters, however, given the public nature of crimes, it will not be that easy to apportion this jurisdiction to both or one of them only.

A recently issued governmental document ${ }^{69}$ has proposed inter alia that "in cases of crimes that are punishable by simple imprisonment or upon complaint, the investigation or trial can be interrupted if the disputing parties have settled their differences through reconciliation and upon the initiation or request of the parties" 70 and that charges may not be pressed because of public interest "if the prosecution is of the opinion that the conflict between the accused and the victim can be better handled through customary laws and institutions than the formal justice system and [ the gravity of the crime is no bar to this]". ${ }^{71}$ This is a policy document and it needs further enabling legislative acts. Importantly, this may have to include constitutional amendments.

The number of prisoners serving short prison terms is very significant compared to the rest. ${ }^{72}$ Thus, the possibility of diverting 'minor' as well as 'serious' criminal cases to the informal system is a beacon to a possible harmonious coexistence of the two systems. How this will be reflected in the procedure and substantive laws, however, remains to be seen.

69) Council of Ministers, Criminal Justice Policy of the Federal Democratic Republic of Ethiopia (Megabit, Addis Ababa, 2003 EC-2011 GC), Articles 3(9)(b), 3(12)(c) and 3(12)(e). The document is written in Amharic and these parts are translated by the author.

70) Ibid., Article 3(12)(e).

71) Ibid., Article 3(12)(c).

72) For further details see Central Statistics Agency (CSA), supra note 28, Law and Order. 


\subsection{Enforcement of Sanctions}

The absence of enabling legislations raises an issue of enforceability of sanctions rendered by the informal system, for so far, the formal system has no legal remit to do so. Future laws should, therefore, address this issue and spare the informal system from being a system without real teeth.

\subsection{Review of Judgements}

It is shown above that no appeal lies from the decisions of the informal system, for they do not belong to the same court system structured hierarchically. Thus, whether the formal courts should be given the remit to hear appeals from the informal courts is an issue that needs to be addressed in future legislation. It will be advisable for formal courts to be denied to hear such appeals except for those

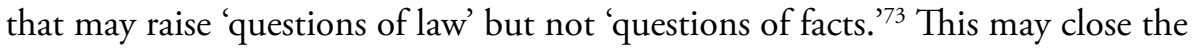
door for opportunistic forum shopping and lessen the burden of the formal courts. Thus, provided that litigants are advised to choose their forums judiciously, no fault should be deemed to exist when they are denied the right to reinstitute their cases at another court outside of the formal hierarchy.

\subsection{Lessons to be Learnt from the Shari'a Courts' Law}

Although any discussion pertaining to religious laws and courts does not fall within the ambit of this article, it appears that a brief discussion on the virtues of the relevant law will be in order. Accordingly, Proclamation No. 188/1999 that re-established the former Khadi and Naiba councils established by law in $1942^{74}$ provides inter alia that: Sharia courts shall have jurisdiction over, [personal and family matters in general]; their substantive law is Islamic law, while the procedural law is the national Civil Procedure law; parties are required to give express consent to the jurisdiction - by signing on the summons - and failure to record objection either on the summon or by appearing before the registrar will lead to a presumption of acceptance of the jurisdiction; once a case is consented to, it cannot be transferred from one court to the other. This is to say that the case has

\footnotetext{
73) Pursuant to Article79(1) of the Ethiopian Constitution, "Judicial powers, both at the Federal and State levels", are vested in the courts. Moreover, per Article 80(3)(a) and 80(3)(b) of the same, "The Federal Supreme Court has a power cassation over any final court decision containing a basic error of law .... and the State Supreme Court has power of cassation over final court decisions on state matters that contain basic errors of law."

As the practice in the country shows, issues that pertain to the constitutionality of customary laws or the decision of informal courts, as well as their incompatibility with International or Regional Human Rights Instruments are entertained by State Supreme Courts or the Federal Supreme Court. This should also apply to appeals from informal courts.

74) For further details on these courts, see Norman J. Singer, 'Islamic Law and the Development of the Ethiopian Legal System' (1971-1973) 17 Howard Law Journal 130; and Mohammed Abdo, 'Legal Pluralism, Sharia Courts and Constitutional Issues in Ethiopia' (2011) 5 Mizan Law Review 72-104.
} 
to exhaust all remedies in a court that has taken initial jurisdiction and that a party cannot seek change of venue at will. And their decisions are enforced by the formal state organs. It will be hoped that the future enabling legislation covering other areas of the customary legal system will emulate the virtues of this law, for they may help to alleviate the current problems that have afflicted the relationship between the two systems.

\section{Conclusion}

It helps to note that so many projects sponsored by foreign organizations that aim at reforming the justice system are under way. ${ }^{75}$ Almost all these projects have addressed the major issues touched upon in this article plus legal aid and the protection and promotion of human rights, among others. Some of them have also shown positive results. The formal system will be emboldened by these projects and claim the upper hand, if not in the immediate future, but through gradual evolution and sometime in the coming few decades. The sensitization of human rights carried out for some years after enactment of the 1995 Constitution and the responses of the traditional societies towards the abolition of 'harmful traditional practices' - such as female genital mutilation, early marriage, etc. - that are expressly proscribed under the 2004 Criminal Code, bear witness to the possibility of a harmonious relationship between the two systems if done through healthy dialogues. ${ }^{76}$

Thus, as I have argued in this article, given the high rate of urbanization witnessed in recent years as well as the different attempts made to reform the formal judicial system, it is hoped that the future is for the formal system to prevail over the informal. The same cannot be said about the informal system for there are no records that show any such tendency. It is therefore recommended that pertinent institutions should adopt a two pronged approach to facilitate the transition to the ultimate goal of assimilation. Firstly, the short term policy should focus on legislating relevant statutes that empower the informal system to handle as many civil cases that do not raise serious human rights issues plus less serious criminal cases. Secondly, in the long term, the policy should focus on strengthening the formal system by helping it overcome its current shortcomings such as delays and corruption.

\footnotetext{
75) See, inter alia: Center for International Legal Cooperation, supra note 57, CLEP, supra note 57, The World Bank supra note 57, and National Judicial Institute for the Canadian International Development Agency, Independence, Transparency and Accountability of the Judiciary of Ethiopia (October, 2008).

76) See Haile Gebriel Dagne, Fisseha Haile Meskel and Tilahun Teshome, Enabling Communities Abandon Harmful Traditional Practices, with special reference to Female Genital Mutilation, Early Marriage, Marriage by Abduction and Perinatal Harmful Traditional Practices (Addis Ababa, 2004).
} 